\title{
ZBYNĚK ZBYSLAV STRÁNSKÝ: ŽIVOT A DÍLO

\section{PAVEL HOLMAN}

Když se řekne československá muzeologie 2. poloviny 20. století, znalým se vybaví zejména tři osobnosti, které zde zakládaly a rozvíjely muzeologii jako vědní obor, ale také výukový obor na vysokých školách - Jiří Neustupný, Josef Beneš a Zbyněk Zbyslav Stránský. K nim bychom mohli přiřadit ještě Jiřího Špéta jako předního odborníka na dějiny českého muzejnictví. Bohužel čas je neúprosný a tyto osobnosti nás postupně opouštěly, zanechavše zde svoje dílo a také žáky a následovníky. Bohužel 21. ledna 2016 odešla i poslední z těchto osobností Zbyněk Zbyslav Stránský, zakladatel brněnské muzeologické školy, spoluzakladatel postgraduálního muzeologického studia a externí katedry na brněnské univerzitě a zakladatel katedry muzeologie a denního studia muzeologie na téže škole. S ním odešla poslední z osobností, které můžeme nazvat zakladateli české muzeologie a jejího mezinárodního věhlasu. Z. Z. Stránský byl osobou, která formovala teoretické základy muzeologie a podílela se také na tvorbě řady výstav a expozic $\mathrm{v}$ československých muzeích a památkových objektech a koncepcích mnoha muzeí. Své stopy zanechal také jako univerzitní pedagog a to prostřednictví svých žáků, které učil kritickému muzeologickému myšlení.

Zbyněk Zbyslav Stránský se narodil v Kutné Hoře dne 26. října 1926. Ale rodiče se brzy přestěhovali do Pardubic a později do Bratislavy. Na jeho zájmy a pozdější profesní směřování měly vliv povolání a zájmy jeho rodičů - matka byla profesorkou jazyků se zájmem

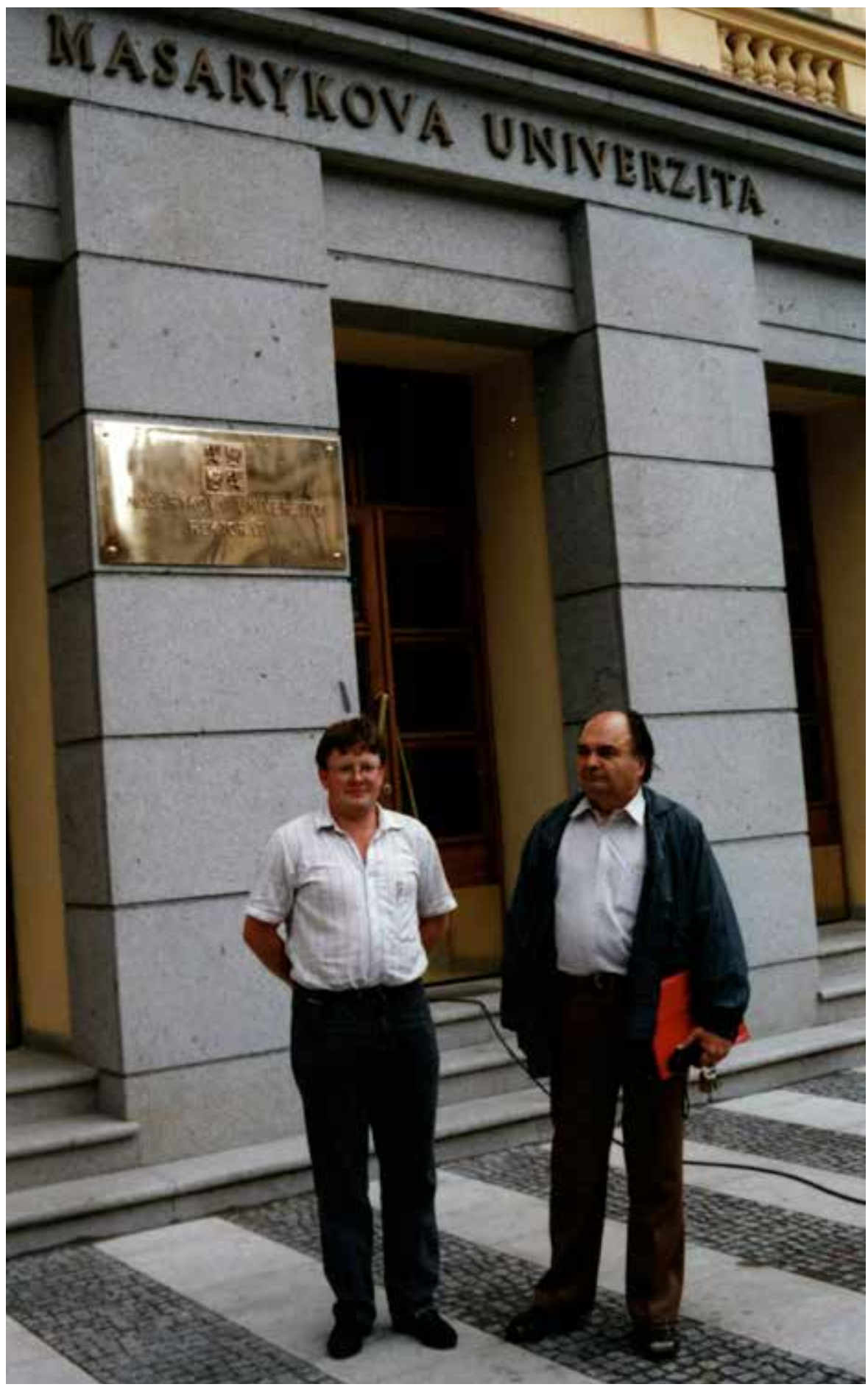


o hudbu, otec, profesí chemik, se zajímal o dějiny techniky a technické muzejnictví. Muzejnictví, resp. muzeologie se staly pro Zbyňka

Z. Stránského nejen povoláním, ale i posláním. Hudba pak celoživotním koníčkem.

V Bratislavě započal i středoškolská studia. Město ale musel s rodiči opustit na začátku 2. světové války, kdy se přestěhovali do Prahy. Zde také dokončil stř̌ední školu. Po skončení války, v roce 1946, nastoupil na Filozofickou fakultu Karlovy univerzity, obor filozofie a historie. Studia ukončil v roce 1950. Kromě toho také vystudoval externě muzikologii na Masarykově univerzitě v Brně. Po skončení studia nastoupil do muzea v České Brodě a poté do Muzea Antonína Dvořáka (součást Národního muzea). Zároveň pracoval i ve Společnosti Antonína Dvořáka. V roce 1952 nastoupil do Hellichova muzea v Poděbradech, kde se stal také ředitelem. Jeho zásluhou se muzeum stalo Krajským muzeem Pražského kraje. Za jeho působení začalo muzeum vydávat odborné periodikum Muzejní zprávy Pražského kraje, ve kterém hojně publikoval, včetně muzeologicky zaměřených článků. $\mathrm{V}$ roce $1958 \mathrm{z}$ poděbradského muzea odešel do Muzea Vysočiny $\mathrm{v}$ Jihlavě.

Zásadní zlom v životě Z. Z. Stránského přrišel v roce 1962 . Tehdejší ředitel Moravského muzea v Brně, světově uznávaný antropolog, a můžeme také říci muzeolog, Jan Jelínek $\mathrm{v}$ rámci organizačních změn v muzeu zřídil také muzeologické oddělení. To mělo plnit funkci metodického, teoretického a dokumentačního centra a Zbyněk Z. Stránský se stal jeho pracovníkem. Zde mohl plně uplatnit a rozvíjet muzeologii jako vědu.

Hned po příchodu na muzeologické oddělení se zapojil do aktivit na poli muzeologie, které rozvíjel Jan Jelínek. Předně to bylo znovuobno- vení vysokoškolské výuky muzeologie v Brně na filozofické fakultě. $\mathrm{V}$ roce 1921 zde Jaroslav Helfert zřídil lektorát muzejnictví, který ale zanikl s jeho odchodem $\mathrm{z}$ Brna do východních Čech na počátku 50. let 20. století. Jan Jelínek a s ním i Zbyněk Z. Stránský si uvědomovali nutnost speciální príipravy budoucích a stávajících muzejních pracovníků na práci v muzeích, na což je speciální studium jednotlivých vědních oborů zastoupených v muzeích nepřipraví. Proto usilovali o otevření takového studia v Brně. Po jednáních s vedením Univerzity Jana Evangelisty Purkyně a vedením Filozofické fakulty UJEP schválily vědecké rady těchto institucí otevření postgraduálního studia muzeologie a zř́izení externí katedry muzeologie. Dalšími jednáními a př́ípravou studia byl pověřen Jan Jelínek. Postupně se podařilo připravit studijní plán, získat akreditaci a na podzim 1964 byl otevřen první běh postgraduálního studia muzeologie. Na všech př́ípravách se podílel i Zbyněk Z. Stránský, který se také aktivně zapojil jako jeden $\mathrm{z}$ vyučujících. Výuka v této formě studia probíhal až do poloviny 90 . let 20. století. Celkem bylo realizováno 15 běhů a studium ukončilo cca 300 absolventů. S otevřením denního studia muzeologie zájem o tuto formu studia klesal, a proto byla ukončena.

Důležitým počinem muzeologického oddělení Moravského muzea a externí katedry muzeologie Filozofické fakulty UJEP bylo uspořádání muzeologického symposia v roce 1965. Účastnila se ho řada osobností české a slovenské muzeologie a muzejnictví, včetně nestora oboru Jiřího Neustupného. Zásadní příspěvky přednesl Jan Jelínek, který hovořil o potřebě muzeologie pro muzejnictví a její výuce na vysokých školách, a zejména Zbyněk Z. Stránský. Ten ve svých prríspěvcích hovořil ve dvou rovinách jednak o muzeologii jako vysokoškolském studijním oboru a jeho studijním programu, jednak o muzeologii jako vědním oboru, jeho předmětu, systému a terminologii. Poprvé zde Zbyněk Z. Stránský představil svoje pojetí muzeologie, jeho předmět a systém. Upozornil na dílo svých předchůdců, počínaje Klimentem Čermákem a konče Jiřím Neustupným a Stránského současníkem Josefem Benešem. Prezentoval rovněž názory zahraničních muzeologů, jako byl Georges Henri Riviére, Alma S. Wittlin, H. A. Konnr aj. Na základě srovnání přístupů konstatuje, že předmětem zájmu muzeologie nemohou být jen muzea, ale i další formy sběratelství a speciálního přístupu lidí ke skutečnosti.

Svoje pojetí muzeologie Stránský pak prezentoval v několika vydáních Úvodu do studia muzeologie, z nichž první vyšlo $v$ roce 1972 (další v letech 1979 a 1984, v roce 1993 vyšla speciální verze pro posluchače Mezinárodní letní školy muzeologie a to v české, anglické a francouzské verzi, česká upravená verze vyšla ještě $v$ roce 2000) a také v řadě dílčích článků publikovaných u nás i v zahraničí.

\section{Zbyněk Z. Stránský stál rovněž} u zrodu významného muzeologického časopisu nazvaného Muzeologické sešity. Tento časopis vydávala Univerzita Jana Evangelisty Purkyně, Moravské muzeum a Moravská galerie počínaje rokem 1969. Tento časopis vycházel až do roku 1986. Vyšlo celkem 10 řádných čísel a 3 supplementa, $v$ nichž svoje články publikovala řada předních našich i zahraničních muzeologů. Z pohledu výuky muzeologie v Brně je zajímavé II. Supplementum z roku 1974, celé věnované historii výuky od roku 1963, včetně studijních plánů. Toto číslo vyšlo i v angličtině a ruštině. Muzeologické sešity ve své době sehrály důležitou roli muzeologického teoretického časopisu, který doposud u nás nevycházel. Bohužel, pokusy o jeho 
restart v první polovině 90 . let skončily neúspěchem.

Díky publikační činnosti Stránského muzeologie vešla do širšího povědomí odborné veřejnosti u nás i v zahraničí a umožnila mu se zapojit do řady mezinárodních aktivit. At’ již na půdě ICOMu nebo $\mathrm{v}$ roce 1977 založeného ICOFOMu, tedy výboru pro muzeologii (zakladatelskými osobnostmi byli např. Jan Jelínek, Peter van Mensch, Vinoš Sofka aj.). Z pověření Ministerstva kultury se od roku 1978 podílel na práci mezinárodního týmu připravujícího slovník Dictionarium museologicum, který pak vyšel v roce 1983. Práce trvala několik let a přípravný tým vydával průběžné zpravodaje, kde byly prezentovány aktuální problémy a výsledky. Výsledný slovník byl nakonec koncipován jako překladový. Vedoucím jazykem byla angličtina. K anglickému termínu pak byl přrřazen ekvivalent $\mathrm{v}$ dalších 19 jazycích. Na české části pracoval právě Zbyněk Z. Stránský a Oskar Brůža. Na konci knihy pak byl zkušební výkladový slovník některých termínů. Předpokládalo se, že právě na výkladovém muzeologickém slovníku bude mezinárodní tým dále pracovat. Bohužel se členové nedokázali shodnout na tom, jak pokračovat a činnost týmu byla ukončena. Muzeologický terminologický výkladový slovník je dodnes restem, který teoretická muzeologie má. Ve svých publikacích se o základní terminologii pokoušel i Z. Z. Stránský, ale samostatný slovník nevydal. Ten publikoval nakonec Josef Beneš pod názvem Muzeologický slovník, ale ten zapadl a širšího ohlasu se nedočkal. Pokusy o slovník najdeme v zahraničí, kde v některých zemích takovéto slovníky vyšly. Od počátku 90. let 20. století na takovémto slovníku pracuje francouzský muzeolog Andrée Desvallées a jeho tým. Výsledek byl nedávno publikován.

Mezinárodní renomé Z. Z. Stránského a brněnské muzeologické školy bylo značné. Z. Z. Stránskému to umožnilo vytvořit mezinárodní projekt školy, která by zahraničním účastníkům prezentovala výsledky brněnské muzeologie a také sem přivedla zahraniční muzeology, kteří by prezentovali svoje názory a svoje pojetí oboru. Projekt byl připravován pod záštitou UNESCO od roku 1983. V roce 1986 pak byla zřízena Mezinárodní letní škola muzeologie - International Summer School of Museology (ISSOM) a byl otevřen první běh základního kurzu, který měl posluchačům formou přednášek, cvičení a exkurzí prezentovat celý systém muzeologie. Zpočátku vytvářel pro účastníky jisté překážky tehdejší režim, ale škola fungovala a brzy si v zahraničí získala značné renomé. Obsahovou náplň školy a výběr zahraničních přednášejících připravoval Zbyněk Z. Stránský (po roce 1989 se na tom $v$ některých případech podílel i Vinoš Sofka), organizační stránku měla na starosti pracovnice Sekretariátu ISSOM, kterých se na tomto místě vystřídalo několik. Od roku 1986 se každý rok uskutečnil jeden běh základního kurzu. Od roku 1994 navrhl Z. Z. Stránský, na základě ohlasů od posluchačů, pořádat i kurzy speciální, zaměřené např. na muzejní management, muzejní výstavnictví a sbírkotvornou činnost. Od tohoto roku se každoročně pořádal bud' základní kurz a jeden specializační, nebo dva specializační. Někteří posluchači absolvovali i více kurzů. Byli i tací, kteří ukončili všechny vypisované kurzy. ISSOM byla úspěšná škola, které se zúčastnili posluchači a vyučující ze všech kontinentı̊, vyjma Austrálie, a jak jsem uvedl výše, někteří přijeli několikrát jako studenti, ale také nejprve jako studenti a následně i vyučující. Po odchodu Z. Z. Stránského na Slovensko, na Univerzitu Mateja Bela, se ve vedení školy vystřídali Krasimir Damjanov, Vinoš Sofka a Jan Dolák. Poslední kurs se pak uskutečnil v roce 2000.

\section{Z. Z. Stránský nezapomínal ani} na výuku muzeologie na brněnské univerzitě, ani na práci v muzeologickém oddělení Moravského muzea. V Moravském muzeu postupně budoval odbornou muzeologickou knihovnu, do které získával jak české publikace a časopisy, tak i zahraniční tituly. V těch případech, kdy nebylo možné získat knihu samotnou, byly pořizovány fotokopie. Týkalo se to zejména starší a staré muzeologické literatury, počínaje Samuelem Quicchenbergem, Johannem Danielem Majorem, Casparem Friedrichem Neickeliem atd. Vznikla tak cenná sbírka muzeologické literatury od nejstarší známé (Quicchenbergovo Inscriptiones vel tituli theatri amplissimi z roku 1565) až po 20. století. Další cennou sbírku, kterou Z. Z. Stránský budoval, tvoří soubor diapozitivů, zachycující dobovou podobu československých a zahraničních muzeí, nebo soubor diapozitivů zachycující podobu historických sbírek, doprovázejících přednášky $\mathrm{z}$ dějin sběratelství a muzejnictví. Muzeologické oddělení bylo také teoretickým a metodickém pracovištěm, na kteréžto činnosti se Stránský také podílel. Po jeho odchodu na Masarykovu univerzitu muzeologické oddělení postupně zaniklo, vytvořené fondy byly ale převedeny do Knihovny Moravského zemského muzea.

\section{Z. Z. Stránský se také snažil rozvíjet} výuku postgraduálního studia muzeologie. Zejména v sedmdesátých letech prošel výukový program některými reformami a byla posílena zejména teoretická výuka. Snahy akreditovat také denní výuku muzeologie zatím vycházely naprázdno. To se Zbyňku Z. Stránskému podařilo až po roce 1989. V roce 1992 bylo akreditováno denní studium muzeologie a založena Katedra muzeologie. Studium bylo již tehdy koncipováno jako dvoustupňové, bakalářské a na to navazující magisterské, což bylo tehdy na českých 
vysokých školách neobvyklé, ale brzy se tento systém stal standardem. $V$ roce 1993 pak byl otevřen první ročník bakalářského studia a první ročník magisterského studia (do něj nastoupili absolventi muzeologie ze Slezské univerzity, kde bylo tehdy pouze bakalářské studium). Od té doby se výuka muzeologie stále rozvíjí. Již Z. Z. Stránský začal budovat nezbytnou základnu každého vysokoškolského oboru, jako je odborná knihovna a i nezbytné technické vybavení. S tím mu pomáhal i Pavel Holman, který na katedru nastoupil jako odborný asistent $\mathrm{v}$ roce 1993. $\mathrm{V}$ roce $1994 \mathrm{se}$ podařilo získat také část knihovny zrušeného Ústředního muzeologického kabinetu (v té době přejmenované na Muzejní informační a studijní službu) Národního muzea. Tím byla knihovna posílena o řadu cenné literatury vydávané českými a později i slovenskými muzei od 19. století a také literaturou zahraniční. Pomocí grantů bylo získáno potřebné technické vybavení, které obohatilo výuku a usnadnilo pracovníkům práci.

Otevření hranic v roce 1989 umožnilo Z. Z. Stránskému širší zapojení do mezinárodních aktivit, kterých se mohl zúčastnit i osobně. Účastnil se tak různých zasedání ICOMu i ICOFOMu a dalších muzejních a muzeologických institucí a univerzit.

V roce 1996 odchází Z. Z. Stránský do důchodu, ale ještě do roku 1998 působí jako ředitel ISSOM a také přednáší na Katedře muzeologie, která byla ale mezitím spojena s archeologií do Ústavu archeologie a muzeologie. V roce 1998 zakládá na Univerzitě Mateja Bela v Banské Bystrici Katedru ekomuzeológie, kterážto působila na odloučeném pracovišti v Banské Štiavnici. Katedru vedl až ro roku 2002, kdy odchází do důchodu.

I poté je zván na různé přednášky a akce, jak na Slovensku ale i dal- ších evropských zemích. K osmdesátinám Z. Z. Stránského je uspořádána $\mathrm{v}$ Technickém muzeu $\mathrm{v}$ Brně mezinárodní konference, která má připomenout jeho dílo, ale také prezentovat nové směry $\mathrm{v}$ muzeologii. Referáty zde přednesla řada jeho spolupracovníků a žáků.

Postupně se ale Zbyněk Zbyslav Stránský stahoval z veřejného života, i díky vážné chorobě, kterou onemocněl. Jeho srdce dotlouklo $\mathrm{v}$ ranních hodinách dne 21 . ledna 2016. Jeho muzeologické dílo bude dále žít nejen $\mathrm{v}$ jeho publikacích, ale i v odkazu, který předal svým žákům v bohaté pedagogické kariéře, a kteří jeho myšlenky uplatňují v každodenní praxi. At je to používání termínů, které zavedl, jako muzeálie, muzealizace aj., nebo v přístupu k jednotlivým činnostem v muzeích. Jeho odkaz je také dále rozvíjen i na Oddělení muzeologie Ústavu archeologie a muzeologie Filozofické fakulty Masarykovy univerzity v Brně, kterou zakládal.

\section{PAVEL HOLMAN}

muzeolog, Brno

Česká republika

\section{ZBYNĚKK ZBYSLAV STRÁNSKÝ: LIFE AND WORK}

\section{PAVEL HOLMAN}

When somebody mentions Czechoslovak museology of the 2nd half of the 20th century, those who are in the know will mainly imagine three figures who founded and developed here museology as a scholarly discipline, but also as a field of university studies - Jiří Neustupný, Josef Beneš and Zbyněk Zbyslav Stránský. Among them we could also count Jiří Špét as a top expert in the history of Czech museums. Time is unfortunately merciless and these personalities gradually passed away, leaving here their work as well as disciples and followers. It is sad enough that on 21 January 2016 passed away the last of these personalities, Zbyněk Zbyslav Stránský, founder of the Brno museological school, co-founder of postgraduate museology studies and external Chair at the Brno university, and founder of the Chair of Museology and full-time museology studies in the same school. With him left the last of figures whom we can call the founders of Czech museology and originators of its international renown. Z. Z. Stránský was a person who formed the theoretical foundations of museology and participated in creation of many temporary and permanent exhibitions in Czechoslovak museums and listed monuments, and development of conceptions of many museums. He also left his legacy as a university pedagogue through the medium of his disciples, whom he taught critical museological thinking.

Zbyněk Zbyslav Stránský was born in Kutná Hora on 26 October 1926. But his parents soon moved to Pardubice and later to Bratislava. His interests and later professional career were influenced by occupations and interests of his parents mother was professor of languages, interested in music, father was chemist, interested in the history of technology and technical museums. Museums, or museology, became to Zbyněk Z. Stránský not only an occupation but also mission. Music was his lifelong hobby.

In Bratislava he began to study in a secondary school. But he and his parents had to leave the town at the beginning of World War II, when they moved to Prague. Here he completed his secondary school education. After the end of the war, in 1946, he began to study at the Faculty of Arts, Charles University, in the fields of philosophy and history. He completed his studies in 1950. Besides this he also at- 
tended part-time musicological studies at the Masaryk University in Brno. After completion of studies he started to work in the Museum of Český Brod and afterwards in the Antonín Dvořák Museum (part of the National Museum). At the same time he also worked in the Antonín Dvořák Society. Since 1952 he worked in the Hellich Museum in Poděbrady where he also became Director. It was his merit that the museum became Regional Museum of the Prague Region. Under him the museum began to issue a specialized periodical Muzejní zprávy Pražského kraje (Museum Reports of the Prague Region) in which he published many papers, inclusive of museologically focused articles. In 1958 he left the Poděbrady Museum and came to the Museum of Vysočina Region in Jihlava.

An important milestone in the life of Z. Z. Stránský came in 1962.

The then Director of the Moravian Museum in Brno, world-recognised anthropologist, and we can also say museologist, Jan Jelínek within the scope of organisational changes in the museum also established a museological department. It was intended to play the role of a methodical, theoretical and documentation centre, and Zbyněk Z. Stránský was employed in this department. Here he could apply museology to the fullest extent and develop it as a science.

Immediately after being employed in the museological department, he became involved in activities in the field of museology, which have been pursued by Jan Jelínek. Among them was above all the re-opening of museology studies at the Faculty of Arts in Brno. In 1921, Jaroslav Helfert established here the Lectorate in Museum Studies which, however, was dissolved after his departure from Brno to South Bohemia in the early 1950s. Jan Jelínek and Zbyněk Z. Stránský were aware of the fact that any future or pre- sent museum workers need a special professional training which is not included in specialized studies of individual disciplines involved in museums. That is why they made efforts to open such study programme in Brno. After negotiations with management of the University of Jan Evangelista Purkyně and its Faculty of Arts, the scientific boards of these institutions approved the opening of postgraduate museology studies and establishment of an external Chair of Museology. Another negotiations and preparation of studies were entrusted to Jan Jelínek. The curriculum was gradually set up, accreditation was gained, and the first run of postgraduate museology studies was opened in the autumn of 1964. Zbyněk Z. Stránský participated in all these preparatory works and he also took an active part as one of the teachers. Teaching in this form of study has taken place until the mid1990s. A total of 15 runs of studies were realised, and about 300 graduates have completed their studies. After implementation of full-time museology studies, the interest in this form of study experienced a decrease and the postgraduate studies were therefore terminated.

An important action of the museological department of the Moravian Museum and the external Chair of Museology of the Faculty of Arts UJEP was the organisation of a museological symposium in 1965 . It was attended by many personalities of Czech and Slovak museology and museums, including a doyen of the discipline, Jiří Neustupný. Crucial papers were presented by Jan Jelínek, who spoke about the necessity of museology for museums and about museology tuition in universities, and mainly by Zbyněk Z. Stránský. The latter spoke in his presentation about two levels about museology as a field of university studies and its curriculum, and about museology as a scholarly discipline with its subject, system and terminology. Zbyněk Z. Stránský introduced here for the first time his concept of museology, its subject and system. He turned attention to the work of his predecessors, beginning with Kliment Čermák and ending with Jiří Neustupný and Stránský's contemporary Josef Beneš. He also presented the opinions of foreign museologists, such as Georges Henri Riviére, Alma S. Wittlin, H. A. Konnr a. o. On the basis of a comparison between approaches he claims that the matter of museological interest need not to be only museums but also another forms of collecting activity and special approach of humans to reality.

Stránský presented his special concept of museology in several editions of the Introduction to $\mathrm{Mu}$ seology Studies, the first of which appeared in 1972 (the next ones in 1979 and 1984, in 1993 appeared a special version for the students of International Summer School of Museology in Czech, English and French language, and another modified Czech edition was published in 2000) and in many partial articles published in our country and abroad.

Zbyněk Z. Stránský also participated in foundation of an important museological journal titled Muzeologické sešity. This periodical was published by the University of Jan Evangelista Purkyně, Moravian Museum and Moravian Gallery from 1969 to 1986 . The total of 10 regular issues and 3 supplements published contained articles by top Czech and foreign museologists. Interesting with regard to museology studies in Brno is the II Supplement from 1974, which is dedicated to the history of museology tuition since 1963, including the curricula. This issue was also published in English and Russian language. Muzeologické sešity played an important role of a museological theoretical journal, which has not yet 
been published in our country until that time. The attempt to revive the journal in the first half of the 1990s unfortunately failed.

Thanks to Stránskýs publishing activity, museology became widely known among the professional public in our country and abroad and enabled him to take part in international activities within ICOM or, since 1977, within ICOFOM, that is International Committee for Museology (among the founders were, for example, Jan Jelínek, Peter van Mensch, Vinoš Sofka a. o.). On the authority of the Ministry of Culture he participated since 1978 in the work of an international team preparing the Dictionarium museologicum, which was then published in 1983. The work lasted several years and the preparatory team continuously issued newsletters which featured topical problems and results. The final book was conceived as a translation dictionary. The main language was English and each English term was associated with equivalents in another 19 languages. The Czech part was elaborated by Zbyněk Z. Stránský and Oskar Brůža. At the end of the book there was a trial explanatory dictionary of several terms. It was supposed that the explanatory museological dictionary will be the next task on which the international team will cooperate. The members unfortunately could not reach an agreement on how to proceed, so that the activity of the team was terminated. The museological terminological explanatory dictionary remained an unfinished issue in theoretical museology. Z. Z. Stránský in his publications also attempted a basic terminology but he did not publish a separate dictionary. Such a work was finally published by Josef Beneš and titled Muzeologický slovník (Museological dictionary), but it sunk into oblivion without finding any wider recognition. Dictionaries were published in several foreign countries. French museologist Andrée Desvallées and his team have bee working on such a dictionary since the 1990s. The result was published recently.

The international renown of Z. Z. Stránský and the Brno museological school was considerably high. It enabled Z. Z. Stránský to work out an international school project which would present to foreign learners the results of the Brno museological school and attract foreign museologists who would present their opinions and conception of the discipline. The project has been prepared under the auspices of UNESCO since 1983. The International Summer School of Museology (ISSOM) was then established in 1986, beginning with the first run of the basic course which should have made the attendants familiar with the whole system of museology through lectures, tutorials and excursions. Some obstacles for the participants were initially generated by the then political regime, but the school functioned and soon it won a quite good reputation abroad. The content of the teaching and the selection of foreign lecturers were prepared by Zbyněk Z. Stránský (after 1989 also in co-operation with Vinoš Sofka), the organisational matters were in the competence of the ISSOM Secretariat where several workers have gradually replaced each other at the same post. One run of the basic course has taken place each year since 1986. Z. Z. Stránský, based on the response from learners, proposed to organise since 1994 as well specialized courses which would be focused on, for example, museum management, museum exhibitions and collecting activity. From that year either a basic course and a specialized course, or two specialized courses were opened each year. Some of the learners completed more than one course. There even were attendants who completed all the courses opened. ISSOM was a successful school, in which stu- dents and teachers from all continents except Australia have taken part and, as I already mentioned above, some of the participants came several times as students, but also first as students and later as teachers as well. After departure of Z. Z. Stránský to the Matej Bel University in Slovakia, the school was led by Krasimir Damjanov, Vinoš Sofka and Jan Dolák who gradually replaced each other. The last course has taken place in 2000 .

\section{Z. Z. Stránský also taught muse-} ology at the Brno university and worked in the museological department of the Moravian Museum. In the Moravian Museum he gradually built up a specialized museological library, for which he acquired both Czech and foreign books and journals. If a book could not be acquired for some reason, a copy was made. This mainly concerned older museological literature, beginning with Samuel Quicchenberg, Johann Daniel Major, Caspar Friedrich Neickel, and others. This way arose a valuable collection of museological literature from the oldest known works (Quicchenberg's Inscriptiones vel tituli theatri amplissimi from 1565 ) to the 20th century. Another valuable collection built up by Z. Z. Stránský comprises an assemblage of projection slides capturing the historical appearance of Czechoslovak and foreign museums, or an assemblage of projection slides featuring the historical collections, which accompanied the lectures in history of collecting activities and museums. The museological department also was a theoretical and methodical workplace, in the activities of which Stránský has taken part. The museological department has gradually declined after his departure to the Masaryk University, but the established collections were transferred to the Library of the Moravian Museum.

\section{Z. Z. Stránský also tried to develop} the postgraduate museology studies. 
The educational programme has mainly been changed and redesigned in the 1970s and focus was laid particularly on theoretical aspects. The efforts to accredit as well the full-time studies were not yet successful at that time. Zbyněk Z. Stránský succeeded with this effort as late as after 1989. In 1992, full-time museology studies were accredited and the Chair of Museology was founded. The education in museology was already at that time conceived as a two-degree study, namely the bachelor's programme and the follow-up master's programme, which was unusual at Czech universities of that time, but this system soon became a standard. The first year of bachelor's studies and the first year of master's studies (attended by museology graduates from the Silesian University where at that time only the bachelor's programme could be studied) were opened in 1993 . Since then, the museology tuition has been constantly developed. It was already Z. Z. Stránský who began to build up the inevitable basis of each field of university studies, namely a specialized library and the necessary technical equipment. In this, he was helped by Pavel Holman, who started to work in the Chair as a fellow in 1993. In 1994, they managed to obtain a part of the library of the dissolved Central Museological Cabinet (at that time renamed to Museum Information and Study Service) of the National Museum. The library was thereby enriched with a lot of valuable literature published by Czech and later also Slovak museums since the $19^{\text {th }}$ century, and with foreign literature as well. Grants helped to obtain the necessary technical equipment, which enriched the teaching and made the educational work easier.

The opening of frontiers in 1989 enabled Z. Z. Stránský a wider participation in activities, in which he also could be personally involved.
He took part in various meetings of ICOM and ICOFOM and other museums and museological institutions and universities.

\section{Z. Z. Stránský was retired in 1996,} but until 1998 he still acted as Director of ISSOM and held lectures in the Chair of Museology, which was in the meantime connected with archaeology and gave rise to the Department of Archaeology and Museology. In 1998 he founded the Chair of Ecomuseology at the Matej Bel University in Banská Bystrica, which operated as a detached department in Banská Štiavnica. He has been the Chair Holder until 2002 when he went into retirement.

Even after being retired, he has been invited to various lectures and events, both in Slovakia and in other European countries. On the occasion of the $80^{\text {th }}$ birthday of Z. Z. Stránský, an international conference was organised in the Technical Museum in Brno. The conference should have remembered his work but also presented new trends in museology. Papers were presented by many of his co-workers and disciples.

However, Zbyněk Zbyslav Stránský gradually withdraw from public life, also due to serious illness from which he suffered. His heart went silent in the morning hours on 21 January 2016. His museological work will live on not only in his publications, but also in the legacy which he left to his disciples during a rich pedagogical career and who put his ideas into everyday practice. Be it the use of terms which he implemented, such as musealia, musealisation, etc., or the approach to individual activities in museums. His legacy has also been further developed in the Department of Archaeology and Museology at the Faculty of Arts, Masaryk University in Brno, which he founded.
PAVEL HOLMAN

museologist, Brno

Czech Republic 